\title{
Ларин А.Н., Дьяченко В.А. \\ Саморегуляция поведения курсанта военного института войск национальной гвардии Российской Федерации как психолого-педагогический феномен
}

Пермский военный институт войск наџиональной гвардии Российской Федераџии (Россия, Пермь»)

doi 10.18411/spc-04-12-2017-08

idsp 000001:spc-04-12-2017-08

Современные условия служебной деятельности военного института войск национальной гвардии Российской Федерации объективно вызывают потребность в научном обеспечении процесса воспитания дисциплинированности у курсантов, призванных из среды молодежи, сформировавшейся в условиях рыночных отношений. Эффективность данного процесса во многом зависит от непрерывного повышения качества воспитания будущих офицеров национальной гвардии Российской Федерации.

Понимание проблем психической саморегуляции в отечественной психологии опирается на работы К.А.Абульхановой-Славской (1980), Б.Г.Ананьева (1966), П.К.Анохина (1980), Н.А.Бернштейна (1966), А.Н.Леонтьева (1975), О.А.Конопкина (1980), В.И.Степанского (1991),Д.Н.Узнадзе (I960) и других.

Возможности применения психической саморегулящи в различных целях исследовались в работах 0.В.Дашкевича (1985 - Регуляция деятельности в экстремальных условиях), Н.Ф.Кругловой (1978 - Повышение надежности деятельности при утомлении), В.Р. Мажина (1985 - Стабилизация деятельности в экстремальных условиях), В.М.Нестерова (1986 - В условиях производства),Ф.И.Филимоненко (1982 - Профилактика утомления) и др.[2]

К изучению психологических аспектов применения психической саморегуляции в учебном процессе обращались Г.В.Буланова (1983), Г.Ш.Габдреева (1990), Э.3.Менделевич (1980), Г.В.Шавырина (1973).

После окончания вуза в подчинении молодых офицеров оказываются военнослужащие по призыву (по контракту), и им приходится выступать в качестве воспитателей, формировать дисциплинированность подчиненных. Поэтому воспитание курсантов в вузе имеет двойную задачу. С одной стороны, дисциплинированность является важным условием успешной профессиональной подготовки будущих офицеров. С другой - грамотно организованная воспитательная работа формирует необходимые в будущем знания, умения и навыки, важные для эффективного выполнения служебных обязанностей. Поэтому курсанты вуза должны не только быть дисциплинированными сами, но и понимать внутренние механизмы, условия, влияющие на формирование дисциплинированного поведения, владеть методическими приемами укрепления дисциплины[6].

По мнению Г. С. Никифорова [3], местоимение «само» обозначает направленность действия на того, кто его производит. Объектом регуляции для человека в данном случае являются его собственные поступки и действия, присущие ему психические явления (процессы, состояния, свойства). Именно в последнем случае, когда человек регулирует собственную психическую сферу, мы имеем дело с психической регуляцией.

Саморегуляция имеет две формы - произвольную и непроизвольную.

Психическая саморегуляция - это воздействие человека на самого себя с помощью слов и соответствующих мыслительных образов. Под психической саморегуляцией понимается психическое самовоздействие для целенаправленной регуляции всесторонней деятельности организма, его процессов, реакций и состояний[1].

Психическая саморегуляция поведения курсанта военного института войск национальной гвардии Российской Федерации в контексте учебной деятельности может 
рассматриваться как своеобразное целенаправленное сознательное воздействие субъекта на подсознательный уровень собственной психики при одновременной включенности в структуру деятельности и удержании цели (задачи) специфическими методами изменения психической активности для повышения успешности выполняемых учебных действий.

Такое понимание психической саморегуляции объясняет осознанное управление некоторыми непроизвольными функциями непосредственно в ходе выполняемой учебной деятельностью, чем достигается высокая успешность выполняемых действий.

Установлено, что в режиме саморегуляции поведения курсанта военного института повышается успешность формирования и закрепления ориентировочной основы действия.

Успешность исполнительной части учебной деятельности может обеспечиваться выполнением необходимых действий в режиме самопрограммирования, когда осознанное управление деятельностью в измененном состоянии сознания осуществляется непосредственно в ходе исполнительных действий.

Применение методик психической саморегуляции поведения курсанта военного института войск национальной гвардии Российской Федерации, чья профессиональная деятельность проходит в условиях эмоционального напряжения, позволяет редуцировать тревогу, страх, раздражительность, конфликтность, активизировать память и мышление, нормализовать сон и вегетативные дисфункции, увеличить эффективность профессиональной деятельности, обучить приемам самостоятельного формирования позитивных психоэмоциональных состояний.

Анализ научной литературы показывает, что методы психической саморегуляции - это способы и приемы непосредственного и опосредованного самовоздействия личности на психику и самоизменения психических процессов, свойств и состояний с целью их нормализации. Под методом формирования психической саморегуляции мы вслед за авторами будем понимать «комплекс методов формирования способности человека к произвольной психической саморегуляции, управлению своим психическим состоянием»[3].

По мнению Х.М.Алиева, среди методов психической саморегуляции как средствами повышения успешности учебной деятельности курсантов и слушателей вузов наиболее целесообразными являются методы управляемой саморегуляции. Механизм повышения уровня управляемой саморегуляции человека основан на принципе подбора индивидуальных приемов путем перебора и принципе обучение на основе повторения. В методике Алиева разработаны конкретные приемы эмоциональной психофизиологической саморегуляции для снятия стресса, превентивного повышения стрессоустойчивости, эмоционального, психического, психофизиологического восстановления

B.Е. Попов считает целесообразными методы по произвольной саморегуляции состояний сознания[4].

Таким образом, среди методов психической саморегуляции наиболее универсальными и эффективными средствами повышения успешности учебной деятельности курсантов и слушателей ввузов являются методы управляемой саморегуляции и произвольной саморегуляции состояний сознания.

Психическая саморегуляция по методам управляемой саморегуляции и произвольной саморегуляции как воздействие субъекта на успешность своей деятельности посредством изменения психической активности путем привлечения ресурсов подсознательного уровня, обеспечивает осознанное управление деятельностью в измененном состоянии сознания непосредственно в ходе исполнительных действий, чем достигается высокая успешность выполняемой учебной 
деятельности курсанта военного института войск национальной гвардии Российской Федерации[4].

$$
* * *
$$

1. Грицай, А. О. Стресс-менеджмент и основы психологическойсаморегуляции: метод.указания / А. О. Грицай;Яросл. гос. ун-т им. П. Г. Демидова. - Ярославль : ЯрГУ,2011. - 64 с.

2. Карсанов Э.Х. Профессиональная ориентация как педагогическое условие подготовки курсантов к самообразовательной деятельности. Вестник Санкт-Петербургского университета МВД России. 2010.

3. Ларин А. Н. К проблеме саморегуляции в процессе физической подготовки курсантов военных институтов войск национальной гвардии Российской Федерации. / А. Н. Ларин, А. В. Дубровский, В. П. Чердынцев // Журнал «Современные проблемы науки и образования». - 2016, № 6. URL: https://www.science-education.ru/ru/article/view?id=25794.

4. Ларин А. Н. Моделирование саморегуляции поведения как средства повышения результативности физической подготовки курсантов военных институтов войск национальной гвардии Российской Федерации. / А. Н. Ларин, А. В. Дубровский // Мир образования - образование в мире.- 2017. -№1 (65). С 210-216.

5. Никифоров, Г. С. Самоконтроль человека / Г. С. Никифоров. - Л., 1989.

6. Прохоров А. О. Функциональные структуры и средства саморегуляции психических состояний // Психологический журнал. - 2005. - Т.26, №2. - С. 68-80.

7. Психология профессионального здоровья / под ред. Г.С. Никифорова. - СПб.: Речь, 2006.

8. Сычев С. Е. Воспитание дисциплинированности у курсантов вузов внутренних войск МВД России // Известия российского государственного педагогического университета им. А.И. Герцена.2007.

\section{Ларин А.Н., Щербань Н.А. \\ Роль саморегуляции в совершенствовании физической подготовке курсантов}

Пермский военный институт войск национальной гвардии Российской Федерации doi 10.18411/spc-04-12-2017-09

(Россия, Пермь»)

idsp 000001:spc-04-12-2017-09

Физическая подготовка в войсках национальной гвардии Российской Федерации направлена на обеспечение необходимого уровня физической подготовленности военнослужащих, способствующего успешному выполнению боевых и других задач. Она должна проводится постоянно не только в мирное, но ив военное время. Однако под воздействием ряда факторов установился «жесткий» стереотип представления у офицеров, заключающийся в необходимости её проведения в мирное время и, прежде всего, в местах постоянной дислокации. Физическая подготовка военнослужащих является одним из главных показателей боеспособности.

Огромную роль в развитии и выполнении служебно-боевых задач войсками национальной гвардии играет уровень физической подготовки обучаемых военных ВУЗОВ. Физическая подготовленность курсантов, как будущих офицеров, оказывает влияние не только на личное выполнение ими своих должностных обязанностей, но и на качество обучения ими подчиненных. Офицер не обладающий необходимыми компетенциями в сфере физической подготовки не имеет возможности в полном объёме проводить занятия с подчиненными и совершенствовать их военно-прикладные навыки.

В свою очередь в процессе обучения курсантов, кроме занятий под руководством преподавателей и офицеров, большое значение имеет основная форма обучения - самоподготовка. В ходе нее обучаемые самостоятельно совершенствует навыки полученные на занятиях по физической подготовке, совершенствует военноприкладные навыки, общий уровень физической подготовки.

Неотъемлемой частью самоподготовки является - саморегуляция. Саморегуляция - комплексное понятие включающее в себя различные виды самоконтроля в ходе выполнения физических упражнений (контроль за утомление, 